\title{
A SALT WASTING SYNDROME IN INFANCY
}

\author{
BY \\ DONALD B. CHEEK and JOHN W. PERRY \\ From the Royal Children's Hospital, Melbourne
}

(RECEIVED FOR PUBLICATION OCTOBER 14, 1957)

\begin{abstract}
A continued loss of sodium and chloride is a well-known phenomenon which occurs during the course of uncontrolled adrenal insufficiency. Such losses are of serious consequence and in children lead to a failure of growth and development, to asthenia and infection. It is well recognized that many of the symptoms of adrenal insufficiency are due to the disturbance in mineral metabolism, and it is not surprising, therefore, that other conditions where excessive amounts of salt are lost from the body occasionally give rise to a picture that resembles, in many respects, adrenal insufficiency. In passing, we can mention fibrocystic disease of the pancreas, hydrocephalus with arachno-ureteric drainage, patients with heart disease who are hypersensitive to mercurial diuretics, cerebral salt wasting, pink disease and salt losing nephritis where there is advanced destruction of the renal parenchyma and tubular resistance to salt-retaining steroids.

This communication considers a case which does not seem to fit into any of the categories in the above list. It is that of an infant, studied over a five-month period, who demonstrated a renal salt wasting condition in the face of otherwise normal kidneys and normal adrenal function and acid-base balance. It will be shown that this salt wasting defect was resistant to desoxycorticosterone acetate and we suggest that the defect may be due to a refractory state on the part of the tubules to endogenous salt-active steroids or mineralo-corticoids.
\end{abstract}

\section{Methods}

Sodium and potassium concentrations for serum, sweat and urine were determined on a direct reading flame photometer (Domingo and Klyne, 1949), or by a direct reading E.E.L. flame photometer. Chloride determinations, serum $p \mathrm{H}$, carbon dioxide content, total body water, total body chloride, were all measured by methods set out in a previous communication (Cheek, 1957). To determine total chloride the volume of distribution of bromide was measured and a micro diffusion method was used as described previously (Cheek and West, 1955). Here the diffusion units of Öbrink (1955) were used (obtained from Rudolf Grave Company, Stockholm, Sweden). These units obviate the need for fixative and for subsequent prolonged washings of the units and increase the accuracy of the method. The variation between duplicate determinations of serum bromide was less than $1 \%$. Before the calculation of the extracellular volume index from the bromide space, $10 \%$ of the injected bromide was deducted from the total injected, to allow for the entrance of $8 \%$ of injected bromide into the red blood cells and for the fact that the volume of distribution of bromide is $1-2 \%$ greater than the chloride space. This correction has been applied previously (Cheek, 1954). Recent work indicates that in the rat almost all the intracellular chloride of the body is in red cells; hence it may be that the corrected $\mathrm{Cl}$ or $\mathrm{Br}$ space in man is a good approximation to true extracellular volume.

Sweat was collected following a pharmacological stimulus similar to a method described (Mauer and West, 1956). Urinary 17-ketosteroid excretion, and corticosteroid excretion were assayed by accepted procedures (Medical Research Council Committee on Clinical Endocrinology, 1951; Reddy, 1954). To assess urea clearance, urine was collected over a 24-hour period according to the technique described by Landis, Elsom, Bott and Shiels (1935).

\section{Case Report}

F.C., a male infant, aged 3 months, was the first-born of parents who had been previously in good health. The mother was admitted to the maternity hospital during the last two months of pregnancy because of an excessive gain in weight, hypertension and albuminuria. Labour was induced and the baby was born two weeks prematurely, weighing $5 \frac{1}{2} \mathrm{lb}$. Labour was not difficult and delivery was uneventful. The infant was breast fed for two and a half months but failed to gain satisfactorily. A dried milk mixture was tried temporarily but at the age of 3 months he was brought to the Royal Children's Hospital because of poor feeding, unsatisfactory weight gain and cyanotic attacks. The cyanotic attacks had been noticed during the previous month, and were not associated with feeding. They were not accompanied 
by sweating or change in respiration but did seem to occur on hot summer days. The infant's weight at 1 month of age was $6 \mathrm{lb} .11 \mathrm{oz}$, at 2 months, $7 \mathrm{lb} .11 \mathrm{oz}$. and on admission at 3 months, $8 \mathrm{lb} .2 \mathrm{oz}$.

Course in Hospital. It was found that the infant took his feeds poorly and that he preferred milk to glucose water. During the first three weeks routine investigations were carried out, and the weight of the infant fell progressively. It became clear that the baby did not maintain satisfactory hydration. The haemoglobin was $11 \mathrm{~g}$. per $100 \mathrm{ml}$. The following investigations revealed no abnormality: subdural taps; lumbar puncture; radiographs of the skull and chest; examination of the urine including microscopic examinations of centrifuged deposits; and a Mantoux test. The blood urea was normal, but once, at a time when the child was poorly hydrated, a level of $67 \mathrm{mg}$. \% was recorded. However, radiographs of the kidneys and intravenous pyelography demonstrated normal findings and a subsequent urea clearance test showed that the infant had normal renal function. Restriction of fluid on more than one occasion produced a urine of 1,020 specific gravity which suggested a satisfactory concentrating ability. A urine chromatogram revealed no abnormal amino acid excretion. No evidence of a congenital heart lesion was found.

On the twenty-second day following admission and at a time when hydration was unsatisfactory, serum electrolyte concentrations were determined (Table 1). Next day the fluid intake was increased by giving $5 \%$ glucose solution by gavage, and on the 24th day the infant had a grand mal convulsion and continued to appear dehydrated and cyanosed with sunken eyes and poor skin turgor. The serum sodium and chloride concentrations dropped to low levels (Na $124 \mathrm{mEq} / \mathrm{l}$. and Cl $75 \mathrm{mEq} / \mathrm{l}$.). Intravenous therapy was at once started: a blood transfusion was followed by $400 \mathrm{ml}$. of isotonic saline and $3 \mathrm{~g}$. of $\mathrm{NaCl}$ 24-hourly were added to the feeds. Desoxycorticosterone acetate (DOCA) was given intramuscularly at a dosage of $2 \mathrm{mg}$. 24-hourly. The response was dramatic, hydration at once improved and body weight increased for the first time. The infant became alert and active and the milk intake rose appreciably.

Two oral glucose tolerance tests showed a flat blood sugar curve but the result of an intravenous test was normal. Radiographs of the adrenal gland showed no calcification and 24-hour urine collections made before steroid therapy contained normal amounts of 17-ketosteroids and corticosteroids. (Adrenal function tests will be discussed presently.) The serum sodium concentration remained near $135 \mathrm{mEq} / \mathrm{l}$. while DOCA and $3 \mathrm{~g}$. of sodium chloride were given 24-hourly (Table 1).

On the 43rd day of study, DOCA was discontinued, but the weight still increased. On the 48th day, salt was stopped and the weight, fluid intake, and serum sodium concentration fell. Dehydration recurred and intravenous saline was again given and $3 \mathrm{~g}$. of salt were again added to the milk. The increase in weight over the next period was not so remarkable. On the 63rd day, DOCA ( $2 \mathrm{mg}$.) was recommenced, to see if there would be any increase in the rate of weight gain. There was not, and on the 69th day the steroid was discontinued.

On the 78th day of study, salt was stopped and again the fluid intake, weight and serum sodium concentration fell $(130 \mathrm{mEq} / \mathrm{l}$.). Hypotonic dehydration returned. For the next week some special investigations were carried out (see below) and on the 86th day salt was again added to the milk feedings, but in the increased amount of $5 \mathrm{~g}$.

TABLE 1

SERUM ELECTROLYTE CONCENTRATION ACCORDING TO NATURE OF TREATMENT

\begin{tabular}{|c|c|c|c|c|c|c|c|}
\hline Day of Study & $\underset{(\mathrm{mEq} / \mathrm{l})}{\mathrm{Na}_{\mathbf{8}}}$ & $\underset{(\mathrm{mEq} / \mathrm{l})}{\mathrm{Cl}_{\mathrm{g}}}$ & $\underset{(\mathrm{mEq} / \mathbf{l})}{\mathrm{K}_{\mathbf{s}}}$ & $\underset{\text { Content }}{\mathrm{CO}_{2}}$ & $p \mathrm{H}$ & $\begin{array}{l}\text { Blood Urea } \\
\text { (mg. \%) }\end{array}$ & $\begin{array}{r}\text { Treatment } \\
\text { (per } 24 \mathrm{hr} \text {.) }\end{array}$ \\
\hline 22 & 137 & 102 & $5 \cdot 6$ & & & 19 & Nil \\
\hline 24 & 124 & 75 & $5 \cdot 0$ & & & & Increased $\mathrm{H}_{2} \mathrm{O}$ intake \\
\hline 30 & 135 & 91 & $5 \cdot 0$ & & & 22 & $\begin{array}{lll}\mathrm{NaCl} & 3 & \mathrm{~g} . \\
\mathrm{DOCA} & 2 & \mathrm{mg} \\
\end{array}$ \\
\hline 40 & 134 & 102 & $4 \cdot 7$ & & & & $\begin{array}{lll}\mathrm{NaCl} & 3 \mathrm{~g} . \\
\mathrm{DOCA} & 2 & \mathrm{mg} .\end{array}$ \\
\hline 48 & 130 & 105 & $4 \cdot 5$ & & & & Nil \\
\hline 58 & 136 & 90 & $5 \cdot 9$ & & & & $\mathrm{NaCl} 3 \mathrm{~g}$. \\
\hline 72 & 145 & 93 & $6 \cdot 4$ & & & & $\mathrm{NaCl} 3 \mathrm{~g}$. \\
\hline 78 & 130 & 97 & $4 \cdot 8$ & $24 \cdot 0$ & $7 \cdot 36$ & & Nil \\
\hline 87 & 143 & 98 & $5 \cdot 5$ & $22 \cdot 4$ & - & & $\mathrm{NaCl} 5 \mathrm{~g}$. \\
\hline 99 & 122 & 96 & $5 \cdot 0$ & $19 \cdot 0$ & $7 \cdot 40$ & & DOCA 4 mg. \\
\hline 105 & 138 & 100 & $5 \cdot 5$ & $23 \cdot 3$ & $7 \cdot 36$ & 22 & $\mathrm{NaCl} 5 \mathrm{~g}$. \\
\hline 120 & 142 & 108 & $4 \cdot 2$ & $21 \cdot 8$ & - & & $\mathrm{NaCl} 5 \mathrm{~g}$. \\
\hline 127 & 144 & 110 & $5 \cdot 0$ & $23 \cdot 0$ & $7 \cdot 35$ & & $\mathrm{NaCl} 5 \mathrm{~g}$. \\
\hline 134 & 150 & 105 & $5 \cdot 1$ & $24 \cdot 0$ & & & Nil \\
\hline
\end{tabular}


in the 24 hours. Weight increased rapidly by more than $1 \mathrm{lb}$., hydration was restored and the serum sodium concentration rose to $143 \mathrm{mEq} / \mathrm{l}$. For the next week there was $\mathrm{no}$ further increase in weight.

On the 93rd day, salt therapy was replaced by $4 \mathrm{mg}$. of DOCA 24-hourly. With this treatment weight did not decrease further, but hydration seemed poor as evidenced by the sunken eyes and poor tissue turgor. The infant became lethargic and disinterested in feeding. After six days of steroid therapy his serum sodium concentration had fallen to $122 \mathrm{mEq} / \mathrm{l}$. DOCA was then stopped and replaced by $5 \mathrm{~g}$. of sodium chloride in the milk. Wellbeing returned and the infant began to thrive again. His serum sodium concentration rose to normal levels.

He was discharged to the Out Patients' Department on the 105th day and examined at weekly intervals. On the 133rd day of study, salt ( 5 g. 24-hourly) was discontinued but the patient continued to progress satisfactorily (Fig. 1). At 8 months of age he appeared

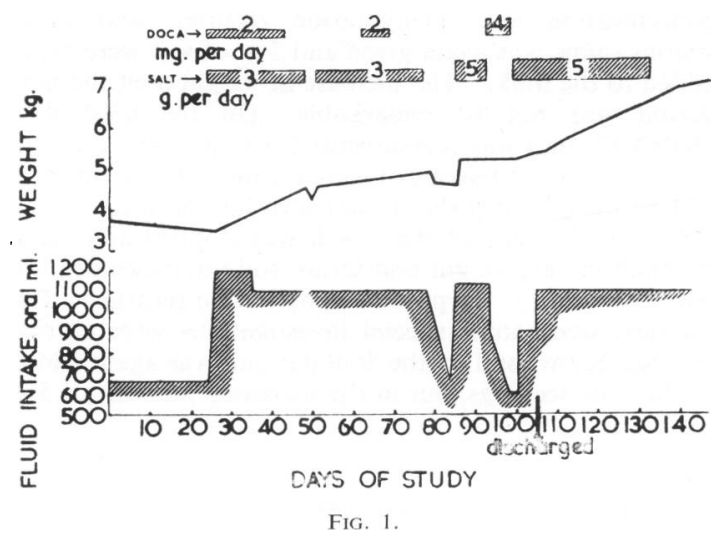

normal but undersized. His weight $\left(15 \frac{3}{4} \mathrm{lb}\right.$.) fell on the third percentile of the weight chart.

Special Investigations. In Table 2 the results of investigation of steroid excretion are recorded. Repeated determination of 17-ketosteroid and 11-oxysteroids in the urine demonstrated normal excretion and the response following $25 \mathrm{mg}$. of ACTH (gel) per day for a three-day period was also normal. The Thorn eosinophil test was performed and disclosed normal function in so far as the eosinophil level dropped progressively from 150 to 11 cells per c.mm. over a three-hour period. On the previous day, two spot counts had revealed 233 and 166 cells per c.mm. These tests with ACTH were carried out during the 78th to 85th day when no therapy was being given. Also during this period, when the weight had reached a low level, determination of electrolyte intake and urine output was made (81st day). The sodium, chloride, and potassium intake was $13 \cdot 7,15 \cdot 8$ and 16.5 milliequivalents per day respectively while the urine output contained $12 \cdot 3,15 \cdot 9$ and 8.4 milliequivalents for sodium, chloride and potassium. Hence the
TABLE 2

EXCRETION LEVEL OF URINE STEROIDS ACCORDING TO NATURE OF TREATMENT

\begin{tabular}{|c|c|c|c|c|}
\hline Day of Study & Corticoste & $\begin{array}{l}\text { etosteroids } \\
\text { hr.) }\end{array}$ & Trea & $\begin{array}{l}\underset{24 \mathrm{hr} .)}{\operatorname{atment}} \\
2\end{array}$ \\
\hline 24 & $2 \cdot 9$ & $0 \cdot 18$ & & Nil \\
\hline $\begin{array}{c}52-57 \\
\text { (4-day collection) }\end{array}$ & $1 \cdot 2$ & $0 \cdot 19$ & $\mathrm{NaCl}$ & $3 \mathrm{~g}$. \\
\hline 82 & 0.9 & $0 \cdot 17$ & & Nil \\
\hline $\begin{array}{c}83-6 \\
\text { (3-day } \\
\text { administration) } \\
86\end{array}$ & - & 0.66 & $\begin{array}{l}\mathrm{ACTH} \\
\mathrm{NaCl}\end{array}$ & $\begin{array}{l}25 \mathrm{mg} \text {. } \\
5 \mathrm{~g} .\end{array}$ \\
\hline
\end{tabular}

intake and urine output for sodium and chloride closely paralleled one another, and if we consider the expected skin losses for these electrolytes (about 2 milliequivalents per day) the data suggest a negative balance for sodium and chloride. However, balance data derived from such a short period cannot be regarded as very significant.

Data for sweat electrolyte concentrations are set out in Table 3. It can be seen that there was no excessive loss

TABLE 3

SWEAT ELECTROLYTE CONCENTRATIONS ACCORDING TO NATURE OF TREATMENT

\begin{tabular}{c|c|c|c}
\hline Day of Study & $\begin{array}{c}\mathrm{Na} \\
(\mathrm{mEq} / \mathrm{l} .)\end{array}$ & $\begin{array}{c}\mathrm{K} \\
(\mathrm{mEq} / \mathrm{l} .)\end{array}$ & $\begin{array}{c}\text { Treatment } \\
(\text { per 24-hr. })\end{array}$ \\
\hline 36 & $11 \cdot 4$ & $20 \cdot 6$ & $\begin{array}{c}\text { DOCA 2 mg. } \\
\mathrm{NaCl} 3 \mathrm{~g} .\end{array}$ \\
\hline 51 & $16 \cdot 4$ & $18 \cdot 0$ & $\mathrm{Nil}$ \\
\hline 55 & $11 \cdot 1$ & $14 \cdot 4$ & $\mathrm{NaCl} 3 \mathrm{~g}$. \\
\hline
\end{tabular}

of electrolyte from the skin, in fact, the values for sodium and potassium, when the patient was receiving no treatment, are at the lower limit of normal (Cooke, Pratt and Darrow, 1950). When DOCA and/or salt was given the value for sweat sodium was slightly lower.

While the serum sodium concentrations fluctuated with the addition to or subtraction of salt from the food (Table 1)-DOCA exhibiting no sodium retaining effectthe data for serum chloride, carbon dioxide content and hydrogen ion concentration suggest that there was no gross departure from a normal state of acid-base balance.

In Table 4 are recorded the urine sodium and potassium concentrations before and after an intravenous injection $(2.5 \mathrm{mg}$.) of water soluble DOCA. It would seem from these investigations that no appreciable sodium retaining effect was exhibited by the steroid.

In Table 5 data for patient F.C.'s total chloride, extracellular volume and total body water at various stages of treatment are presented. By difference we can record the status of intracellular hydration. For comparison with F.C. we have listed the normal range of values for the corresponding weight of a normal infant, and, for contrast, those of an infant with adrenal hyperplasia and insufficiency and dehydration. 
TABLE 4

Na/K RATIO IN URINE BEFORE AND AFTER 2.5 MG. DOCA I.V. (93rd DAY)

\begin{tabular}{c|c|c}
\hline Flow (ml./30 min.) & $\mathrm{Na(mEq/l.)}$ & $K(\mathrm{mEq} / \mathrm{l})$. \\
\hline $4 \cdot 8$ & 71 & 26 \\
\hline $4 \cdot 2$ & 80 & 26 \\
\hline $3 \cdot 3$ & 90 & 27 \\
\hline$\rightarrow$ I.V. DOCA $2 \cdot 5 \mathrm{mg}$. & 100 & 27 \\
\hline $4 \cdot 0$ & 104 & 27 \\
\hline $5 \cdot 7$ & & \\
\hline
\end{tabular}

Patient F.C. had a significantly low total body chloride and calculated extracellular volume while on no treatment (48th day), or following six days of DOCA (4 mg. 24-hourly) (98th day). Total body water was not low in the first instance but normal. Since no weight was lost $4 \mathrm{mg}$. of DOCA were substituted for salt therapy on the 93rd day, it could be assumed that total water was also normal at that juncture. The data suggest that in both of these periods there was an increase in cell hydration. Three weeks after discharge (127th day) data for total chloride and water and extracellular volume were again obtained. The total chloride and extracellular volume were slightly low but within normal limits.

The infant with adrenal hyperplasia and dehydration showed a reduction of total chloride and extracellular volume. The total water was reduced and the calculated index for intracellular volume also appears low.

From these results it seems that the fluid volume changes in patient F.C. resemble those found in simple sodium loss.

\section{Discussion}

The investigations of infant F.C. lead us to the tentative conclusion that there can be in infancy a salt wasting syndrome that is not directly related to the adrenal gland or to gross renal disease. We are aware that, in chronic nephritis with destruction of renal nephrons, a renal tubular salt wasting syndrome can arise which is resistant to DOCA, as Thorn, Koepf and Clinton (1944), have clearly demonstrated. However, the routine methods of revealing disease of renal nephrons carried out in the case of patient F.C. supported the belief that renal function was normal and urine chromatography did not indicate a tubular defect in amino acid metabolism. On the other hand, investigation into adrenal function disclosed no abnormality. The serum potassium concentration was never grossly elevated, nor was there an obvious disturbance in acid-base balance. The sweat concentration in patient F.C. was not elevated as it is in Addison's disease (Conn and Louis, 1950). Such findings suggest that patient F.C. was not deficient in endogenous mineralo-corticoid. The urine steroid excretion before and following ACTH showed a normal pattern of response and the Thorn eosinophil test was also normal. At the completion of this study the patient was normal emotionally and mentally and there was no reason to believe that disease of the central nervous system was present.

In a patient with adrenal insufficiency with salt wasting one might expect that the withdrawal of salt and a high dosage of DOCA (4 mg. 24-hourly)

TABLE 5

TOTAL CHLORIDE AND VOLUME MEASUREMENTS IN INFANT F.C. (SALT-WASTER) COMPARED WITH NORMAL VALUES AND WITH THOSE IN INFANT H.O. WITH ADRENAL INSUFFICIENCY

\begin{tabular}{|c|c|c|c|c|c|c|c|c|c|c|}
\hline \multicolumn{5}{|c|}{ Infant } & \multirow{2}{*}{$\begin{array}{r}\begin{array}{r}\text { Weight } \\
\text { (Kg.) }\end{array} \\
4 \cdot 5\end{array}$} & \multirow{2}{*}{$\frac{\begin{array}{c}\text { *Total Cl} \\
(\mathrm{mEq} / 1 .)\end{array}}{166}$} & \multirow{2}{*}{$\frac{\begin{array}{c}\text { E.C.V. } \\
(\mathrm{ml} .)\end{array}}{1,240}$} & \multirow{2}{*}{$\frac{\begin{array}{c}\text { T.B.W. } \\
(\mathrm{ml} .)^{+}\end{array}}{3,000}$} & \multirow{2}{*}{$\frac{\begin{array}{c}\text { State of } \\
\text { Intracellular } \\
\text { Hydration }\end{array}}{+}$} & \multirow{2}{*}{$\begin{array}{c}\begin{array}{c}\text { Treatment } \\
\text { (per } 24 \mathrm{hr} .)\end{array} \\
\mathrm{NaCl} \text { for } 24 \mathrm{hr} .\end{array}$} \\
\hline F.C. (salt-waster) & . & $\cdots$ & $\cdots$ & . & & & & & & \\
\hline Normal & $\cdots$ & . & . & $\cdots$ & $4 \cdot 5$ & $183-203$ & $1,530-1,710$ & $3,081-3,239$ & & \\
\hline F.C. & . & . & $\cdots$ & $\cdots$ & $5 \cdot 2$ & 172 & 1,420 & & $?+$ & $\begin{array}{l}\text { After } 6 \text { days DOCA } \\
(4 \mathrm{mg} .)\end{array}$ \\
\hline Normal & . & $\cdots$ & . & $\cdots$ & $5 \cdot 2$ & $205-225$ & $1,720-1,900$ & & & \\
\hline F.C. $\underset{\text { (salt-waster) }}{\text {. }}$ & $\cdots$ & . & $\cdots$ & $\cdots$ & $6 \cdot 35$ & 272 & 1,970 & 4,500 & & $\mathrm{NaCl} 5 \mathrm{~g}$ \\
\hline Normal & . & . & . & $\cdots$ & $6 \cdot 35$ & $271-29 i$ & $2,300-2,480$ & $4,340-4,561$ & & \\
\hline H.O. (Adrenal insu & & & & & $5 \cdot 6$ & 152 & 1,370 & 2,720 & - & \\
\hline Normal & $\cdots$ & . & $\ldots$ & .. & $5 \cdot 6$ & $217-237$ & $1,830-2,010$ & $3,822-4,018$ & & \\
\hline
\end{tabular}

* For infants of 2-9 Kg., $\mathrm{Cl}_{\mathrm{t}}=30 \cdot 7$ weight $(\mathrm{Kg})+.55 \cdot 0(\mathrm{SD} \pm 10 \mathrm{mEq} / \mathrm{l}).(\mathrm{Cheek}, 1954)$

+ E.C.V. = Bromide space corrected for intracellular $\mathrm{Br}(10 \%)$. See p. 252.

$\ddagger$ T.B.W. = Total body water. Normal values and range derived from data of Friis-Hansen (1957). 
would lead to uninterrupted progress. One would not expect deterioration and a fall of serum sodium concentration nor would one expect to find, following such high steroid dosage, a reduction of extracellular volume and loss of total body chloride with a probable increase in cell hydration. Yet these are the changes that took place and, furthermore, intravenous administration of water soluble DOCA did not alter the urine sodium/potassium ratio. It seems reasonable to believe that patient F.C. was not sensitive to DOCA at the level of the renal tubules, and that the therapeutic agent that did guarantee well-being was additional sodium chloride. It is probable that the addition of $3 \mathrm{~g}$. of $\mathrm{NaCl}$ was not optimal and that $5 \mathrm{~g}$. per day was more beneficial. Progress in weight and serum sodium concentrations support this belief. Jaudon (1946, 1948) described what he believed to be a fractional insufficiency of the salt and water hormone of the adrenal gland in the early period of life. Asthenia, failure to thrive, cyanosis, failure to maintain hydration, were characteristic of his group of infants. But Jaudon also reported low urinary steroid excretion, hypoglycaemia, a dramatic response to DOCA without salt, and acidosis, none of which were observed in patient F.C.

It would seem from our observations that we may be dealing with renal tubules that are refractory for a time to salt-retaining steroids. The diminished extracellular volume in patient F.C. should have initiated an increased production of aldosterone (Bartter, Liddle, Duncan, Barber and Delea, 1956) which in turn should have enhanced renal tubular reabsorption of sodium. It would seem that this was not the case. Yet the low sweat sodium values suggest an adequate endogenous production of saltretaining steroids. So we arrive at the suspicion that the renal tubules were sensitive neither to endogenous nor exogenous salt-retaining hormone.

The finding of a flat oral glucose tolerance curve on two occasions while the intravenous curve was normal was of interest. In adrenal insufficiency the gastric absorption of glucose is delayed, but this phenomenon is due to coincidental salt depletion and not to lack of cortical hormone (Althausen, Anderson and Stockholm, 1939; Clark and MacKay, 1942).

While we have been unable to find any similar case reports in the literature, Payne (1954) states that he believes a renal tubular salt wasting condition occurs in infancy and that it is resistant to DOCA. He states that such a condition can threaten for a time the life of an infant but after several weeks spon- taneous recovery takes place. The condition was thought not to be related to adrenal insufficiency. It is felt that the present paper supports this contention but further patients and scientific data will be necessary for study before one can accept these findings as representative of a new syndrome. Although the routine renal investigations are normal one cannot be positive that parenchymal disease is not present and is yet to become manifest.

\section{Summary}

The case is presented of an infant who failed to thrive and to maintain hydration satisfactorily. He was found to have a renal salt wasting defect. Adrenal and kidney function and acid-base balance were found to be normal. Low sweat electrolyte levels were taken as evidence of adequate production of mineralo-corticoid.

This deleterious clinical situation could be reversed by raising the serum concentration to normal with the addition of $5 \mathrm{~g}$. of sodium chloride to the milk intake. When the patient was off salt or on DOCA only, the serum sodium concentration, the extracellular volume and the total chloride fell or were low and the clinical condition deteriorated. DOCA had no effect on the urinary sodium/potassium ratio.

If electrolyte concentration of sweat is a satisfactory index of endogenous mineralo-corticoid production, then this child's salt wasting condition may be related to a transient disturbance in the response of the renal tubules to this hormone.

We are most grateful to Dr. Robert Southby, the Senior Physician responsible for this patient, for allowing us to undertake these investigations, and to Dr. Ian Robinson for much practical help. Urine steroid determinations were undertaken through the assistance of Miss Anne Moore.

REFERENCES

Althausen, T. L., Anderson, E. M. and Stockholm, M. (1939). Proc.

Soc. Exp. Biol. (N.Y.), 40, 342.
Bartter, F. C., Liddle, G. W., Duncan, L. E., Barber, J. K. and Delea, C.. (1956). J. clin. Invest., 35, 1306.

Cheek, D. B. (1954) Pediatrics, 14, 5. (1957). Ibid., 19, 68.

and West, C. D. (1955). J. clin. Invest., 34, 1744.

Clark, W. G. and MacKay, E. M. (1942). Amer.J. Physiol., 137, 104.

Conn, J. W. and Louis, L. H. (1950). J. clin. Endocr., 10, 12.

Cooke, R. E., Pratt, E. L. and Darrow, D. C. (1950).' Yale J. Biol. Med., 22, 227.

Domingo, W. R. and Klyne, W. (1949). Biochem. J., 45, 400.

Friis-Hansen, B. (1957). Acta paediat. (Uppsala), 46, Suppl. 110.

Jaudon, J. C. (1946). J. Pediat., 29, 696.

- (1948). Ibid., 32, 641 .

Landis, E. M., Elsom, K. A., Bott, P. A. and Shiels, E. (1935). J. clin. Invest., 14, 525 .

Mauer, A. M. and West, C. D. (1956). Amer. J. Dis. Child., $92,160$.

Mauer, A. M. and West, C. D. (1956). Amer. J. Dis. Child., 92, 160. (1951). Lancet, 2, 585.

Öbrink, K. J. (1955). Biochem. J., 59, 134

Payne, W. W. (1954). Postgrad. med. J., 30, 476.

Reddy, W. J. (1954). Metabolism, 3, 489.

Thorn, G. W., Koepf, G. F. and Clinton, M. (1944). New Engl. J Med., 231, 76. 